\title{
Decalepis hamiltonii (Wight \& Arn.) Fortified Jaggery: Its Physico-chemical Characterization and Studies on its In vitro Biological Activities
}

\author{
C. Vinutha ${ }^{1}$, M. A. Harish Nayaka ${ }^{2 *}$, G. Sowmyashree ${ }^{3}$ and Dinesh Kumar ${ }^{4}$
}

${ }^{1}$ Department of Biochemistry, College of Agriculture, University of Agricultural Sciences,

Dharwad, Hanumanamatti, Haveri-581115, Karnataka, India

${ }^{2}$ Department of Sugar Technology, Sir M. Visvesvaraya Post Graduate Centre, University of Mysore, Mandya-571402, Karnataka, India

${ }^{3}$ Department of Biochemistry, Mount Carmel College Autonomous, Bengaluru-560052,

Karnataka, India

${ }^{4}$ Department of Chemistry, Bipin Bihari Science PG College, Jhansi-284001,

Uttar Pradesh, India

*Corresponding author

\section{A B S T R A C T}

\section{Keywords}

Jaggery, Decalepis

hamiltonii,

Antioxidant

activity,

Antilipoxygenase

activity,

Antihelmintic

activity

Article Info

Accepted:

12 December 2020

Available Online:

10 January 2021
Jaggery fortified with Decalepis hamiltonii (Swallow root) at $0.05 \%, 0.1 \%$ and $0.2 \%$ (w/v) concentrations using Co 86032, Co419 and Co 62175 varieties sugarcane juice studied for physicochemical characteristics and in-vitro biological activities viz., antioxidant, antilipoxygenase and antihelmintic activities. Physico-chemical analysis of fortified jaggery showed dose proportional reduction incolour, filterability and increased turbidity, insoluble solids, total phenol, protein and flavonoid contents irrespective of sugarcane varieties. DPPH radical scavenging activity and reducing power potential of $D$. hamiltonii fortified jaggery indicated higher antioxidant potential. At $0.2 \%$ D. hamiltonii concentration, jaggery of Co 86032, Co 419 and Co 62175 varieties indicated an $\mathrm{EC}_{50}$ of $3.139,3.048$ and $3.166 \mathrm{mg} / \mathrm{mL}$, respectively for radical scavenging activity and exhibited $5.23,34.47$ and $11.43 \%$ increased reducing power ability compared to control. D. hamiltonii fortified jiggery showed enhanced lipoxygenase inhibitory effect in all cane varieties. At $0.05 \% \mathrm{D}$. hamiltonii fortification, jaggery of Co 86032, Co 419 and Co 62175 varieties showed lipoxygenase activity inhibition with an $\mathrm{EC}_{50}$ of $0.33,0.31$ and $0.32 \mathrm{mg} / \mathrm{mL}$, respectively. Further, positive correlation was observed between total phenolics and DPPH radical scavenging activity $(r=0.909,0.894$ and 0.992$)$ and between total phenolics and lipoxygenase inhibitory activity $(r=0.967,0.894$ and 0.964$)$ for Co 86032, Co 419 and Co 62175 jaggery, respectively. Antihelmintic activity was evident in both control and fortified jaggery samples. D. hamiltonii fortified jaggery might serve as value added natural sweetener for better health wellness.

\section{Introduction}

The past decades has seen for significant outbreak in search of traditional medicine for primary health care and health promotions. Aerobic organisms normally generate reactive oxygen species (ROS) during cellular respiration, an important metabolic 
phenomenon to fuel biological activities. The generation of ROS such as superoxide anion $\left(\mathrm{O}_{2}{ }^{-}\right)$, hydrogen peroxide $\left(\mathrm{H}_{2} \mathrm{O}_{2}\right)$ and hydroxyl radicals $(\mathrm{OH})$ is an inescapable consequence during metabolic respiration in body. So formed free radicals are very unstable and react with bodily chemical groups or substances like DNA, proteins and lipids to cause oxidative destruction (Lu et al., 2010; Craft et al., 2012) leading to cell or tissue injury. Antioxidants are heterogeneous molecules that prevent, protect or delay the extent of oxidative injury to the target biomolecules (Halliwell, 2007) by terminating oxidation chain reactions. Interestingly, majority of aerobic organisms have coevolved with oxidative defense systems to combat ROS mediated oxidative damage. The defense mechanism includes antioxidant enzymes like superoxide dismutase, catalase, peroxidase and glutathione peroxidase, and nonenzymatic antioxidants like vitamin $\mathrm{C}$, vitamin E, glutathione, etc., to protect cells and tissues against ROS harm. Various stress conditions and environmental exposures like tobacco smoke, radiations and other chemical contaminants normally leads to uncontrolled formation of ROS in the body. When there is an imbalance between ROS production and neutralization by body's antioxidant defense systems lead to development of many oxidative stress related degenerative diseases including diabetes (Robertson and Harmon, 2006), cancer (Valko et al., 2006), cardiovascular diseases and aging (Braca et al., 2002; Singh and Jialal, 2006). Antioxidant either synthesized naturally in organisms or supplemented through diet quenches free radicals and decreases the threat of oxidative damage (Knekt et al., 1996). Many synthetic antioxidants (i.e, butylated hydroxytoulene (BHT), butylated hydroxyanisole (BHA) and tert-Butyl hydroquinone (TBHQ)) have used in food industries since decades as a food preservative to prevent oxidative deterioration. However, most of the regulatory guidelines questioned for its toxicity (Grice, 1988; Wichi, 1986; Wang et al., 1998; Guan et al., 2006). There is an inverse relationship between dietary supplementation of antioxidant rich food and incidence of oxidative mediated human diseases (Sies, 1993) and trusted that higher intake of dietary antioxidant combats against the frequency of oxidative stress diseases (Ames et al.,1993).Hence, greater attention received in search and research of antioxidants found naturally in dietary and medicinal plant resources.

The Father of Medicine, Hippocrate's quotes "Let food be thy medicine and medicine be thy food" is the origin of the concept of "Medicine and Food are isogonics" and model of nutraceuticals or functional foods. The term Nutraceuticals, a class of natural products is a hybrid of nutrition and pharmaceutical that serves as a connecting bridge between food and drugs (Adelaja and Schilling, 1999). The use and value of nutraceuticals in food has a long history and long been renowned for health promotions with little scientific evidence of nutrition and medicinal benefits. Currently, nutraceuticals has emerged as a potential food product in the market (Dillard and German, 2000) as the consumers are more alert and eager to know the advanced functional foods and its nutritive significance. The ancient system of Indian medicine (Ayurveda) has documented for the medicinal value of many plants and herbs. Plant diet including herbs, spices, tea, fruits, vegetables, coffee and cacao contribute for total antioxidant capacity and recognized for the beneficial effect on human health (Denys, 2013). In fact, some plants are rich sources of phenolic compounds and phytochemical those shown to scavenge free radicals and exhibit other biological activities (Rice- Evans et al., 1995; Brown and Rice-Evans, 1998) to modulate oxidative stress-related effects. The phytochemicals present in plant-rich diet are 
non-toxic that attributes disease prevention and health promotion potentiality. Plant derived antioxidants gained consideration in food industries and pharma-industries for its ability to preserve foodstuffs by preventing oxidation and protect against oxidative damage in biological systems owing to its therapeutic properties and enhancing wellbeing. There is great deal of search of newer natural bioactive components with health endorsing potential in plant resources.

Sugarcane (Saccharum officinarum) is a commercial plant world widely cultivated mainly for manufacture of table sugar (sucrose) and ethanol fermentation. In addition to sucrose, sugarcane also contains various phytochemicals including phenolic compounds that ascribed health-promoting effects (Fontaniella et al., 2003; Duarte Almeida et al., 2006). Jaggery is a nonconventional natural sweetener man-made by concentrating thick syrup of sugarcane juice via heating. Various ayurvedic preparations added jaggery as a 'wholesome sugar' for its preserved good sweetness and health beneficial components. Jaggery is a least processed sweetener retains majority of the phytochemicals present in sugarcane juice than white sugar (table sugar), a pure sucrose. The phytochemicals present in jaggery recognized for various biological activities and health benefits. In vivo studies documented for the protective role of jaggery on lung damage in rats caused by particulate matter (Sahu and Saxena, 1994) and also reduced the incidence of chromosomal aberrations in rats when fed with jaggery (Nrashant et al., 2008). Literature studies revealed that dietary supplementation of jaggery and its extracted phenolic compounds reduced the development of arteriosclerosis in Japanese quails (Okabe et al., 2009) and exhibited various biological activities viz., antioxidant, cytoprotective and antihelmintic activity (Harish Nayaka et al., 2009; Prasad et al., 2010). There is less scientific evidence on nutraceutical role of jaggery in various food or ayurvedic preparations and fortification of jaggery as a functional sweetener to promote both nutrition and medicinal significance. Few reports documented for jaggery fortification with naturally available vitamin$\mathrm{C}$ using Indian gooseberry (Anwaar and Singh, 2010), preparation of jaggery chocolates with coaca and coffee powder enrichment (Khan Chand et al., 2011) and neem fortified jaggery for enhanced antioxidant ability (Vinutha et al., 2014).

Herbs and spices are cuisine dishes during food preparations since ancient times to enhanceits aroma, flavor, color, astringency and other sensory attributes. Apart from sensory effects, herbs and spices also credited potential health supporting effects by exhibiting antioxidant, antiinflammatory, antibacterial, antimicrobial activities and served as natural food preservatives (Smid and Gorris, 1999). Decalepis hamiltonii well known as swallow root or Makaliberu grow wild as a climbing shrub in the forests of peninsular India. It belongs to the family Asclepiadaceae. D. hamiltonii roots have used for making pickles, juices, beverages and in many ayurvedic preparations (Nayar et al., 1978) for its alleged health stimulating properties. D. hamiltonii finds use as a flavoring agent, appetizer, blood purifier and preservative. D. hamiltonii root extracts exhibited potent antioxidant, antimicrobial, cytoprotective, anti-ulcer and gastroprotective activity (Srivastava et al., 2006a, Srikanta et al., 2011 and Devarajan et al., 2002). The present investigation aims to prepare neutraceutical jaggery sweetener by fortification with $D$. hamiltonii extract and to study the physico-chemical characterization, in vitro antioxidant activity, antilipoxygenase activity and antihelmintic activity of $D$. Hamiltonii fortified jaggery of three different sugarcane varieties. 


\section{Materials and Methods}

\section{Chemicals}

All chemicals and solvents used in the experiment were of analytical grade.1,1Diphenyl-2-picrylhydrazyl (DPPH) was purchased from Himedia Laboratories, Mumbai, India and Trolox from Biomol Research Labs, Inc., USA. Other chemicals like Coomassie Brilliant Blue G-250, Gallic acid, Linoleic acid, Quercetin, Trichloroacetic acid (TA), Butylated hydroxytoulene (BHT) and Bovine serum albumin (BSA) procured from SISCO Research Laboratories Pvt. Ltd., Mumbai, India.

\section{Plant material acquisition}

Twelve months old sugarcane varieties namely Co 86032, Co 419 and Co 62175 cultivated on with similar management regimes were obtained from Zonal Agricultural Research Station, V. C. Farm, Mandya 571405, Karnataka. Fresh Decalepis hamiltonii roots purchased from a local vegetable market ( $\mathrm{K} \mathrm{R}$ Market) at Mysore, Karnataka, India and were cut into small pieces, air-dried and ground to fine powder.

\section{Preparation of $D$. hamiltonii fortified jaggery}

D. hamiltonii fortified jaggery were prepared following the method described by Jagannadha Roa et al., (2007). Briefly, Jaggery fortification with $D$. hamiltonii was made at concentrations viz., $0.05 \%, 0.1 \%$ and $0.2 \%$, w/v using Co 86032, Co 419 and Co 62175 varieties sugarcane juice. Milk of lime $\left[\mathrm{Ca}(\mathrm{OH})_{2}\right]$ added to juice to adjust the $\mathrm{pH}$ 6.6. Juice mixture initially boiled for 10 minutes and filtered using muslin cloth. The filtrate juice continued boiling to thick syrup until striking temperature attained. The thick syrup was air cooled and molded. Jaggery prepared without addition of $D$. hamiltonii served as control. All the jaggery samples were stored at $4^{\circ} \mathrm{C}$ in a sealed plastic container for further analysis.

\section{Physico-chemical characterization}

\section{pH, Turbidity, Filterability and Insoluble solids}

$\mathrm{pH}$, Turbidity, Filterability and Insoluble solid content of $D$. hamiltonii fortified jaggery were evaluated following methods described earlier (Guerra and Mujica, 2010). Briefly, jaggery solution $(5 \% \mathrm{w} / \mathrm{v})$ analysed for $\mathrm{pH}$ using $\mathrm{pH}$ meter (Systronics India Pvt. Ltd., India) and turbidity measured by the percentage transmittance at $720 \mathrm{~nm}$ in visible spectrophotometer (Systronics India Ltd. Gujarat, India).

Filterability of jaggery solution was evaluated based on the rate of filtration and pure sucrose $\left(28^{0}\right.$ Brix $)$ served as reference standard. Jaggery and sucrose solutions filtered through Whatman No. 1 filter paper and the percentage of filterability was calculated using the ratio of filtrate volumes. The residue on the filter paper was dried, weighed and analyzed for insoluble solid content of jaggery, and its result was expressed in percentage on dry weight basis.

Color, Water Activity $\left(a_{w}\right)$, moisture and ash content

The color of jaggery in $5 \%(\mathrm{w} / \mathrm{v})$ solution was appreciated based on optical density at $540 \mathrm{~nm}$ using visible spectrophotometer as defined by Mandal et al., (2006). Water activity was determined using a water activity meter (Novasina, Switzerland). Moisture and ash content of jaggery was measured following standard protocols of official AOAC (Helrich, 1990). 
Reducing sugar and non-reducing sugar (Sucrose)

The reducing sugar content of jaggery was estimated by Fehling's method (Lane and Eynon, 1923).Briefly, N/2 jaggery solution $(13 \mathrm{~g}$ in $100 \mathrm{~mL})$ was titrated against Fehling's solution using $1 \%$ methylene blue as internal indicator under hot condition and Dextrose $(0.5 \%$ solution $)$ used as reference standard. Non-reducing sugar (sucrose) content of jaggery was evaluated by ICUMSA method using Double R. Polarimeter (Anon 1999).

\section{Total protein content}

The total protein content of jaggery was quantified by the Bradford's method (Bradford, 1976). Briefly, a sample aliquot of $100 \mu \mathrm{L}$ (3.5 mg jaggery) was added to $900 \mu \mathrm{L}$ of Bradford reagent and the color absorbance recorded at $595 \mathrm{~nm}$ using spectrophotometer. Bovine serum albumin (BSA) was used as a reference standard and the protein content of jaggery was statedin terms of $\mathrm{mg}$ of BSA equivalent/g.

\section{Total phenol content}

The total phenol content of jaggery was estimated spectrophotometrically through Folin-Ciocalteu's method (Singleton et al., 1999). A sample aliquot of $50 \mathrm{mg} / \mathrm{mL}$ of jaggery, $1 \mathrm{~mL}$ of Folin-Ciocalteu reagent (1:2, $\mathrm{v} / \mathrm{v})$ and $2 \mathrm{~mL}$ of $10 \%$ sodium carbonate were sequentially added, incubated for an hourat room temperature and the absorbance was noted at $765 \mathrm{~nm}$. Gallic acid was used as a standard. The total phenolic content of jaggery was expressed as $\mathrm{mg}$ of Gallic acid equivalent (GAE)/g.

\section{Total flavonoid content}

The total flavonoid content of jaggery was determined according to aluminium chloride method (Chang et al., 2002). A sample aliquot $50 \mathrm{mg} / \mathrm{mL}$ of jaggery, $50 \mu \mathrm{L}$ of $10 \%$ aluminium chloride and $50 \mu \mathrm{L}$ of $1 \mathrm{M}$ potassium acetate were serially added, incubated for $30 \mathrm{~min}$ at room temperature and theoptical density recorded at $415 \mathrm{~nm}$. Quercetin was used as a standard and total flavonoid content was expressed in $\mu \mathrm{g}$ of quercetin equivalent $(\mathrm{QE}) / \mathrm{g}$.

\section{In-vitro biological activities}

\section{In-vitro antioxidant activity}

\section{DPPH radical scavenging activity}

The DPPH radical scavenging activity of jaggery was quantified following the method of Yamaguchi et al., (1998). Accordingly, a sample aliquot of jaggery at $10-50 \mu \mathrm{g} / \mathrm{mL}$ and standard antioxidant at $2-10 \mu \mathrm{g} / \mathrm{mL}$ was made up to $200 \mu \mathrm{L}$ using distilled water. $1 \mathrm{~mL}$ of $0.1 \mathrm{mM}$ DPPH was added. The reaction mixture incubated at room temperature in dark for $20 \mathrm{~min}$ and the absorbance was recorded against control at $517 \mathrm{~nm}$. The ability to scavenge DPPH radical was calculated and the result expressed asan effective concentration $\left(\mathrm{EC}_{50}\right)$ for $50 \%$ DPPH radical scavenging activity.

DPPH Radical Scavenging ability (\%) = $\left[\left(\mathrm{A}_{\text {Control }}-\mathrm{A}_{\text {sample }}\right) / \mathrm{A}_{\text {Control }}\right]$ x 100

\section{Reducing power assay}

The reducing power of jaggery was determined following the method of Yen and Chen (1995). Aliquots of jaggery (1-5 $\mathrm{mg} / \mathrm{mL}$ ) and standard antioxidant Trolox (10$50 \mu \mathrm{g} / \mathrm{mL}$ ) was mixed with an equal volume of $0.2 \mathrm{M}$ Phosphate buffer, $\mathrm{pH} 6.6$ and $1 \%$ potassium ferricyanide. The reacting mixture kept warm at $50{ }^{\circ} \mathrm{C}$ for $20 \mathrm{~min}$. Further, an equal volume of $10 \%$ trichloroacetic acid added and centrifuged at $3000 \mathrm{~g}$ for $10 \mathrm{~min}$. 
The supernatant was mixed with distilled water and $0.1 \% \mathrm{FeCl}_{3}$ at a ratio of $1: 1: 2$ (v/v/v), and the absorbance was measured at $700 \mathrm{~nm}$.

\section{In-vitro Antilipoxygenase activity}

\section{Enzyme extraction from soybean}

Lipoxygenase enzyme was extracted from soybean following the method described by Vineet Kumara et al., (2006) with slight modification. Briefly, $10 \mathrm{~g}$ of soybean seed soaked overnight homogenized at $0-4{ }^{\circ} \mathrm{C}$ in $0.2 \mathrm{M}$ phosphate buffer ( $\mathrm{pH}$ 6.8) for 20 minutes using micro-tissue homogenizer. The homogenate centrifuged at $10000 \mathrm{rpm}$ for 10 min at $4{ }^{\circ} \mathrm{C}$ and the supernatant used as crude extract for assaying lipoxygenase activity. The protein content of the crude soybean extract determined by Bradford's method as described earlier.

\section{Lipoxygenase activity}

Lipoxygenase activity was analysed following the method described by (Naidu, 1995). Briefly, $500 \mu \mathrm{L}$ of crude enzyme extract was made up to $2 \mathrm{~mL}$ using $50 \mathrm{mM}$ Tris buffer, $\mathrm{pH} 7.4$ and $1 \mathrm{~mL}$ of $50 \mu \mathrm{M}$ linoleic acid was added. The increase in absorbance of the reaction mixture monitored at $234 \mathrm{~nm}$ wavelength against the blank. One unit of enzyme was equivalent to the enzyme concentration that caused an increase in absorbance of 1.0 per min at $234 \mathrm{~nm}$. The enzyme activity was recorded as $\mu$ moles of hydroperoxide formed per minute per $\mu$ mole of enzyme per volume.

\section{Lipoxygenase inhibitory activity}

Lipoxygenase inhibitory activity of jaggery was analyzed following the method described by Naidu, (1995). An aliquot of jaggery sample $(100-500 \mu \mathrm{g})$ and $500 \mu \mathrm{L}$ of soybean lipoxygenase enzyme and $2 \mathrm{~mL}$ using $50 \mathrm{mM}$ Tris buffer of $\mathrm{pH} 7.4$ taken in test tubes were pre-incubated for 10 minutes at $37{ }^{\circ} \mathrm{C}$. Then, $1 \mathrm{~mL}$ of $50 \mu \mathrm{M}$ linoleic acid substrate was added and mixed well. The absorbance of the reaction mixture monitored at $234 \mathrm{~nm}$ in UV spectrophotometer. Indomethacin served as standard inhibitor. The inhibitory effect of jaggery was recorded in terms of effective concentration $\mathrm{EC}_{50}$ values

Lipoxygenase Inhibition $(\%)=\left[\left(A_{\text {control }^{-}}\right.\right.$ $\left.\left.A_{\text {sample }}\right) / A_{\text {control }} \times 100\right]$

\section{In-vitro antihelminthic activity}

Anti-helminthic activity of fortified jaggery was determined according to the method described by Prasad et al., (2010). The assay performed using adult Indian earthworms (Pheritima posthuma) for their resemblance both anatomical and physiological with the intestinal parasitic roundworm infecting gastro-intestine of human beings. Briefly, six earthworms of equal size placed in petridishes containing fortified jaggery solution $(10 \mathrm{~g} / 20 \mathrm{~mL})$. Piperazine-hexahydrate $(10$ $\mathrm{mg} / \mathrm{mL}$ ) used as standard drug and distilled water as control. The Anti-helmintic activity of jaggery was performed in triplicate trials. The time taken for paralysis (noted when no movement observed except when the worms were shaken vigorously) and the death time of worms (noted ascertaining that worms neither moved when shaken vigorously nor when dipped in warm water, $50^{\circ} \mathrm{C}$ ) were recorded.

\section{Statistical analysis}

All the experiments were carried out in triplicates $(n=3)$ and the results were represented as mean \pm standard deviation (SD) using Microsoft Excel software. IBM SPSS Statistical software version 19.0 was used to analyze the results. 


\section{Results and Discussion}

Physico-chemical characterization of $D$. hamiltonii fortified jaggery

The data of physical characteristics of $D$. hamiltonii fortified jaggery were presented in Table 1. The $\mathrm{pH}$ of $D$. hamiltonii fortified jaggery and its control were slightly acidic and in the range of 5.59 to 5.84 that was in conformity as reported by Guerra and Mujica (2010). Ecuadorian technical standard (2002) has recommended $\mathrm{pH} 5.9$ for jaggery. Turbidity measures the degree of transparency of solution and the presence of suspended particulates. Turbidity of jaggery solution was recorded spectrophot metrically at $720 \mathrm{~nm}$ and results indicated that jaggery fortification with $D$. hamiltonii displayed higher turbidity of three-sugarcane variety jaggery tested. At $0.05 \%$ D. hamiltonii fortification, jaggery of Co 86032, Co 419 and Co 62175 varieties showed 5.8, 8.1 and $6.1 \%$ higher turbidity, respectively than its respective control. Enhanced turbidity of jaggery solution directed greater presence of suspended particulates in jaggery samples. The insoluble solid content of jaggery also showed to increase by $0.4 \%$ with decreased rate of filterability about $0.15 \%$ for Co 86032 and Co 419 jaggery varieties and $0.46 \%$ for Co 62175 jaggery variety. Turbidity of the solution is directly proportionate to insoluble solid content and inversely related to rate of filtration of the jaggery samples. Further, the ash content of fortified jaggery differed by only $0.01 \%$. Increased turbidity and higher insoluble solids in fortified jaggery presumed that the phytochemicals from added $D$. hamiltonii spice extract during jaggery making were retained in final product. The observations viz. increased turbidity, insoluble solids content and decreased filterability of fortified jiggery interprets that $D$. hamiltonii dried powder might not be good clarificant to accomplish sugarcane juice clarification.
The color of jiggery was computed spectrophotometrically based on the absorbance of jaggery solution at $540 \mathrm{~nm}$. Color plays a prominent role in consumer's choice and acceptance of jaggery and its market value. The presence of plant pigments like chlorophylls, xanthophylls, carotenes and anthocyanins intensifies dark color to sugarcane juice. Non-enzymatic browning reactions, caramelization and Maillard reactions during juice boiling further deepen dark coloration to juice (Hodge, 1953; Tomasik et al., 1989). Presence of free reducing sugars, both aldoses and ketoses, in particularly fructose contributes ample dark coloration to jaggery during thermoevaporation (Burton and McWeeny, 1963; Burton et al., 1963). Reduction in color intensity was noticed in jaggery upon fortification with $D$. hamiltonii. At $0.2 \% D$. hamiltonii concentration, jaggery Co 86032, Co 419 and Co 62175 showed 32.2, 24.9 and 27.1\% lower color absorbance than their respective controls. Accordingly, jaggery fortification with $D$. hamiltonii diminishes brown color significantly and imparts better coloration to upsurge its consumer's preference and market demand.

The principal factors of keeping quality of jaggery are its moisture content and water activity. Moisture content of jaggery measures the amount of water in terms of percentage whereas water activity $\left(a_{w}\right)$ quantifies free or active water available to support the growth of microorganisms in jaggery. Moisture content of jaggery both control and fortified samples varied slightly and were in the range of $4-6 \%$ that was in concurrent as reported by Guerra and Mujica (2010). Bureau of Indian Standards, BIS 1990 stated that the moisture content of freshly prepared jaggery must be 5-7\% (Anonymous, 1990). Water activity $\left(a_{w}\right)$ of jaggery was between the values 0.6 and 0.7 that generally benefits for the proliferation of food spoilage 
microbes on jaggery (Beuchat, 1981). Thus, proper hygienic practices may be supportive to improve shelf life of $D$. hamiltonii fortified jaggery.

Chemical characteristic of $D$. hamiltonii fortified jaggery were tabulated in Table 2 . The chief component of jaggery is nonreducing sugar, sucrose; and glucose being major reducing sugar. Reducing sugar content and sucrose content in both control and fortified jaggery at all $D$. hamiltonii concentrations of tested sugarcane varieties remained unchanged. However, the total protein, phenol and flavonoid contents of fortified jaggery of tested sugarcane varieties significantly increased with dose dependent D. hamiltonii addition. The total protein content of jaggery as quantified by Bradford's method was noted between 0.9 and 1.49 $\mathrm{mg} / \mathrm{g}$. At $0.2 \%$ D. hamiltonii fortification, Co 86032, Co 419 and Co 62175 jaggery boosted its total protein content by 23.7, 18.3 and $23.0 \%$, respectively. Further, the total phenol content of Co 86032 and Co 419 fortified jaggery increased by $21.8 \& 19.5 \%$ and flavonoid content by $55.3 \& 65.0 \%$, respectively from their respective control but Co 62175 variety fortified jaggery showed only $2 \%$ and $17 \%$ higher total phenol and flavonoid content, respectively. Polyphenols are the secondary metabolites of the plant kingdom exhibits various biological activities (Duthie and Crozier, 2000; Ghasemzadeh and Ghasemzadeh,2011; Ferrazzano et al., 2011). The dietary sources of polyphenols include fruits, vegetables, spices, cereals, plantderived beverages and natural sweeteners (Scalbertet al., 2005).Our investigation showed that the total phenol and flavonoid contents in jaggery have increased upon addition of $D$. hamiltonii and this enhanced polyphenolic components in fortified jaggery may contribute for itsheightened biological activities.

\section{In-vitro antioxidant activity of $D$. hamiltonii fortified jaggery}

DPPH radical scavenging and reducing power assays employed to evaluate in vitro antioxidant activity of $D$. hamiltonii fortified jaggery. DPPH, a stable free radical used to study the free radical scavenging ability of natural compounds. The principle of the assay includes reduction of absorbance of methanolic DPPH solution at $517 \mathrm{~nm}$ after accepting an electron or hydrogen radical from an antioxidant to form non-radical DPPH. The degree of decolourisation of DPPH with an antioxidant is stoichiometric and inversely proportional to radical scavenging ability of that antioxidant (Blios, 1958). Figure-1 demonstrated the DPPH radical scavenging ability of control and $D$. hamiltonii fortified jaggery of three sugarcane varieties studied. The radical scavenging potential of jaggery and standard antioxidant BTH was expressed as $\mathrm{EC}_{50}$ values (half-maximal effective concentration). Lower the $\mathrm{EC}_{50}$ values of an antioxidant indicate its higher free radical scavenging potentiality. Free radical scavenging ability of an antioxidant relies on its hydrogen donation capacity (Chen and Ho, 1995). The results revealed that the free radical scavenging potentiality of fortified jaggery was dose proportional with $D$. hamiltonii added to jaggery during fortification. At $0.2 \% \quad D$. hamiltonii concentration, Co 86032, Co 419 and Co 62175 fortified jaggery displayed higher DPPH radical scavenging capacity with $\mathrm{EC}_{50}$ values of $3.139,3.048$ and $3.166 \mathrm{mg} / \mathrm{mL}$, respectively and standard antioxidant BHT had $\mathrm{EC}_{50}=0.008 \mathrm{mg} / \mathrm{mL}$, that was only 400 folds lower concentration needed to illustrate free radical scavenging activity than fortified jaggery. However, a good positive correlation ( $r=0.909,0.894$ and 0.992) was established between the phenolic content and DPPH scavenging activity of $D$. hamiltonii fortified jaggery for Co 86032, Co 419 and Co 62175 varieties, respectively. 
Table.1 Physical properties of $D$. hamiltonii fortified jaggery from different sugarcane varieties (Mean \pm Standard Deviation)

\begin{tabular}{|c|c|c|c|c|c|c|c|c|c|c|c|c|}
\hline Sugarcane variety & \multicolumn{4}{|c|}{ Co 86032} & \multicolumn{4}{|c|}{ Co 419} & \multicolumn{4}{|c|}{ Co 62175} \\
\hline $\begin{array}{c}\text { D.hamiltonii } \\
\text { Concentration }\end{array}$ & $\begin{array}{c}0 \% \\
(\mathrm{Ctrl})\end{array}$ & $0.05 \%$ & $0.1 \%$ & $0.2 \%$ & $\begin{array}{c}0 \% \\
(\mathrm{Ctrl})\end{array}$ & $0.05 \%$ & $0.1 \%$ & $0.2 \%$ & $\begin{array}{c}0 \% \\
(\mathrm{Ctrl})\end{array}$ & $0.05 \%$ & $0.1 \%$ & $0.2 \%$ \\
\hline pH & $\begin{array}{r}5.800 \\
\pm 0.040\end{array}$ & $\begin{array}{c}5.840 \\
\pm 0.040\end{array}$ & $\begin{array}{r}5.790 \\
\pm 0.040\end{array}$ & $\begin{array}{r}5.770 \\
\pm 0.040\end{array}$ & $\begin{array}{r}5.690 \\
\pm 0.010\end{array}$ & $\begin{array}{l}5.570 * * \\
\pm 0.010\end{array}$ & $\begin{array}{l}5.640 * \\
\pm 0.010\end{array}$ & $\begin{array}{r}5.690 \\
\pm 0.010\end{array}$ & $\begin{array}{r}5.820 \\
\pm 0.020\end{array}$ & $\begin{array}{r}5.810 \\
\pm 0.050\end{array}$ & $\begin{array}{l}5.640 * * \\
\pm 0.030\end{array}$ & $\begin{array}{l}5.640 * * \\
\pm 0.020\end{array}$ \\
\hline Colour (OD at $540 \mathrm{~nm}$ ) & $\begin{array}{r}0.798 \\
\pm 0.003\end{array}$ & $\begin{array}{r}0.783 \\
\pm 0.018\end{array}$ & $\begin{array}{r}0.773 * * \\
\pm 0.005\end{array}$ & $\begin{array}{c}0.541 * * * \\
\pm 0.011\end{array}$ & $\begin{array}{r}0.904 \\
\pm 0.004\end{array}$ & $\begin{array}{l}0.894 * * \\
\pm 0.001\end{array}$ & $\begin{array}{r}0.745 * * \\
\pm 0.002\end{array}$ & $\begin{array}{c}0.679 * * * \\
\pm 0.002\end{array}$ & $\begin{array}{r}1.157 \\
\pm 0.001\end{array}$ & $\begin{array}{l}1.078^{*} \\
\pm 0.002\end{array}$ & $\begin{array}{l}0.975 * * \\
\pm 0.003\end{array}$ & $\begin{array}{c}0.843^{* * *} \\
\pm 0.004\end{array}$ \\
\hline Moisture (\%) & $\begin{array}{r}5.100 \\
\pm 0.04\end{array}$ & $\begin{array}{l}5.800 * * \\
\pm 0.04\end{array}$ & $\begin{array}{l}5.600 * * \\
\pm 0.03\end{array}$ & $\begin{array}{l}5.800 * * \\
\pm 0.02\end{array}$ & $\begin{array}{r}5.625 \\
\pm 0.030\end{array}$ & $\begin{array}{l}5.100 * * \\
\pm 0.030\end{array}$ & $\begin{array}{l}6.200 * * \\
\pm 0.030\end{array}$ & $\begin{array}{l}6.200 * * \\
\pm 0.030\end{array}$ & $\begin{array}{r}4.800 \\
\pm 0.010\end{array}$ & $\begin{array}{r}4.800 \\
\pm 0.030\end{array}$ & $\begin{array}{l}4.700 * \\
\pm 0.010\end{array}$ & $\begin{array}{r}4.000 * * * \\
\pm 0.010\end{array}$ \\
\hline $\begin{array}{c}\text { Turbidity (\% } \\
\text { Transmittance } \\
\text { at } 700 \mathrm{~nm})\end{array}$ & $\begin{array}{r}36.20 \\
\pm 0.04\end{array}$ & $\begin{array}{c}34.10 * * \\
\pm 0.02\end{array}$ & $\begin{array}{c}33.10 * * * \\
\pm 0.03\end{array}$ & $\begin{array}{c}31.80 * * * \\
\pm 0.04\end{array}$ & $\begin{array}{r}29.60 \\
\pm 0.03\end{array}$ & $\begin{array}{l}27.20 \text { * } \\
\pm 0.03\end{array}$ & $\begin{array}{c}26.10 * * \\
\pm 0.03\end{array}$ & $\begin{array}{c}24.90 * * * \\
\pm 0.03\end{array}$ & $\begin{array}{r}19.60 \\
\pm 0.05\end{array}$ & $\begin{array}{l}18.40 \\
\pm 0.05\end{array}$ & $\begin{array}{c}16.00 * * \\
\pm 0.04\end{array}$ & $\begin{array}{c}14.70 * * * \\
\pm 0.03\end{array}$ \\
\hline Filterability (\%) & $\begin{array}{r}79.17 \\
\pm 0.02\end{array}$ & $\begin{array}{l}79.03 * \\
\pm 0.04\end{array}$ & $\begin{array}{c}78.79 * * \\
\pm 0.03\end{array}$ & $\begin{array}{c}77.35 * * \\
\pm 0.04\end{array}$ & $\begin{array}{r}70.83 \\
\pm 0.03\end{array}$ & $\begin{array}{l}70.68^{*} \\
\pm 0.02\end{array}$ & $\begin{array}{l}70.41^{*} \\
\pm 0.04\end{array}$ & $\begin{array}{l}69.99 * \\
\pm 0.03\end{array}$ & $\begin{array}{r}64.58 \\
\pm 0.02\end{array}$ & $\begin{array}{l}64.12 * \\
\pm 0.03\end{array}$ & $\begin{array}{l}63.85^{*} \\
\pm 0.01\end{array}$ & $\begin{array}{c}63.59 * * \\
\pm 0.02\end{array}$ \\
\hline Insoluble solids (g/100g) & $\begin{array}{r}5.340 \\
\pm 0.02\end{array}$ & $\begin{array}{l}5.720 * * \\
\pm 0.02\end{array}$ & $\begin{array}{l}6.170 * * \\
\pm 0.03\end{array}$ & $\begin{array}{l}6.750 * * \\
\pm 0.02\end{array}$ & $\begin{array}{r}7.390 \\
\pm 0.02\end{array}$ & $\begin{array}{l}7.520 * * \\
\pm 0.03\end{array}$ & $\begin{array}{l}7.590 * * \\
\pm 0.03\end{array}$ & $\begin{array}{c}7.650 * * * \\
\pm 0.01\end{array}$ & $\begin{array}{r}7.530 \\
\pm 0.02\end{array}$ & $\begin{array}{c}7.850 * * \\
\pm 0.02\end{array}$ & $\begin{array}{c}8.130 * * * \\
\pm 0.02\end{array}$ & $\begin{array}{c}8.280 * * * \\
\pm 0.02\end{array}$ \\
\hline Water Activity, $\mathbf{a}_{w}(\%)$ & $\begin{array}{r}0.699 \\
\pm 0.01\end{array}$ & $\begin{array}{c}0.714 * * \\
\pm 0.03\end{array}$ & $\begin{array}{l}0.708^{*} \\
\pm 0.03\end{array}$ & $\begin{array}{c}0.715^{* *} \\
\pm 0.02\end{array}$ & $\begin{array}{r}0.679 \\
\pm 0.03\end{array}$ & $\begin{array}{c}0.712 * * \\
\pm 0.02\end{array}$ & $\begin{array}{c}0.726 * * \\
\pm 0.04\end{array}$ & $\begin{array}{c}0.729 * * \\
\pm 0.06\end{array}$ & $\begin{array}{r}0.689 \\
\pm 0.03\end{array}$ & $\begin{array}{r}0.683 \\
\pm 0.02\end{array}$ & $\begin{array}{l}0.679 * \\
\pm 0.02\end{array}$ & $\begin{array}{l}0.635^{*} \\
\pm 0.03\end{array}$ \\
\hline $\operatorname{Ash}(\%)$ & $\begin{array}{c}0.03 \\
\pm 0.00\end{array}$ & $\begin{array}{c}0.04 \\
\pm 0.00\end{array}$ & $\begin{array}{c}0.04 \\
\pm 0.00\end{array}$ & $\begin{array}{c}0.03 \\
\pm 0.00\end{array}$ & $\begin{array}{c}0.03 \\
\pm 0.00\end{array}$ & $\begin{array}{c}0.04 \\
\pm 0.00\end{array}$ & $\begin{array}{c}0.03 \\
\pm 0.00\end{array}$ & $\begin{array}{c}0.04 \\
\pm 0.00\end{array}$ & $\begin{array}{c}0.03 \\
\pm 0.00\end{array}$ & $\begin{array}{c}0.03 \\
\pm 0.00\end{array}$ & $\begin{array}{c}0.04 \\
\pm 0.00\end{array}$ & $\begin{array}{c}0.04 \\
\pm 0.00\end{array}$ \\
\hline & & & & & & & & & & & & \\
\hline
\end{tabular}

t-test: $* P<0.05 ; * * P<0.01 ; * * * P<0.001$ 
Table.2 Chemical properties of $D$. hamiltonii fortified jaggery from different sugarcane varieties (Mean \pm Standard Deviation)

\begin{tabular}{|c|c|c|c|c|c|c|c|c|c|c|c|c|}
\hline \multirow{2}{*}{$\begin{array}{c}\text { Sugarcane variety } \\
\text { D. hamiltonii } \\
\text { Concentration }\end{array}$} & \multicolumn{4}{|c|}{ Co 86032} & \multicolumn{4}{|c|}{ Co 419} & \multicolumn{4}{|c|}{ Co 62175} \\
\hline & 0\% Ctrl & $0.05 \%$ & $0.1 \%$ & $0.2 \%$ & 0\% Ctrl & $0.05 \%$ & $0.1 \%$ & $0.2 \%$ & 0\% Ctrl & $0.05 \%$ & $0.1 \%$ & $0.2 \%$ \\
\hline Sucrose (\%) & $\begin{array}{r}71.44 \\
\pm 0.01\end{array}$ & $\begin{array}{l}71.41 \\
\pm 0.03\end{array}$ & $\begin{array}{c}71.47 * \\
\pm 0.02\end{array}$ & $\begin{array}{l}71.42 \\
\pm 0.04\end{array}$ & $\begin{array}{l}72.76 \\
\pm 0.01\end{array}$ & $\begin{array}{l}72.79 \\
\pm 0.02\end{array}$ & $\begin{array}{l}73.77 \\
\pm 0.03 \\
\end{array}$ & $\begin{array}{l}73.76 \\
\pm 0.03\end{array}$ & $\begin{array}{l}73.00 \\
\pm 0.03\end{array}$ & $\begin{array}{c}73.28 * \\
\pm 0.03\end{array}$ & $\begin{array}{c}73.54 * \\
\pm 0.02\end{array}$ & $\begin{array}{c}73.73 * \\
\pm 0.03\end{array}$ \\
\hline Reducing sugar (\%) & $\begin{array}{l}17.28 \\
\pm 0.02 \\
\end{array}$ & $\begin{array}{l}17.34 \\
\pm 0.05\end{array}$ & $\begin{array}{l}17.23 \\
\pm 0.04 \\
\end{array}$ & $\begin{array}{l}17.30 \\
\pm 0.07 \\
\end{array}$ & $\begin{array}{l}17.09 \\
\pm 0.01\end{array}$ & $\begin{array}{l}17.12 \\
\pm 0.03\end{array}$ & $\begin{array}{l}17.14 \\
\pm 0.05\end{array}$ & $\begin{array}{l}17.09 \\
\pm 0.03\end{array}$ & $\begin{array}{l}17.42 \\
\pm 0.03\end{array}$ & $\begin{array}{l}17.45 \\
\pm 0.03\end{array}$ & $\begin{array}{l}17.42 \\
\pm 0.03\end{array}$ & $\begin{array}{l}17.48 \\
\pm 0.04\end{array}$ \\
\hline Protein (mg/g) & $\begin{array}{c}0.93 \\
\pm 0.01\end{array}$ & $\begin{array}{l}1.01 * \\
\pm 0.02\end{array}$ & $\begin{array}{l}1.09 * \\
\pm 0.02\end{array}$ & $\begin{array}{l}1.15^{*} \\
\pm 0.03\end{array}$ & $\begin{array}{c}1.09 \\
\pm 0.02\end{array}$ & $\begin{array}{c}1.18 \\
\pm 0.04\end{array}$ & $\begin{array}{l}1.23 * \\
\pm 0.03\end{array}$ & $\begin{array}{l}1.29 * \\
\pm 0.03\end{array}$ & $\begin{array}{c}1.21 \\
\pm 0.04\end{array}$ & $\begin{array}{c}1.23 \\
\pm 0.02\end{array}$ & $\begin{array}{l}1.41 * \\
\pm 0.01\end{array}$ & $\begin{array}{l}1.49 * \\
\pm 0.02\end{array}$ \\
\hline Total Phenol (mg/g) & $\begin{array}{c}3.16 \\
\pm 0.04\end{array}$ & $\begin{array}{c}3.45^{* *} \\
\pm 0.04\end{array}$ & $\begin{array}{c}3.48 * * \\
\pm 0.03\end{array}$ & $\begin{array}{c}3.85 * * \\
\pm 0.04\end{array}$ & $\begin{array}{c}3.43 \\
\pm 0.05\end{array}$ & $\begin{array}{l}3.87 * \\
\pm 0.04\end{array}$ & $\begin{array}{c}3.99 * * \\
\pm 0.04\end{array}$ & $\begin{array}{c}4.10 * * * \\
\pm 0.02\end{array}$ & $\begin{array}{c}3.76 \\
\pm 0.02\end{array}$ & $\begin{array}{c}3.77 \\
\pm 0.02\end{array}$ & $\begin{array}{c}3.79 \\
\pm 0.02\end{array}$ & $\begin{array}{l}3.83 * \\
\pm 0.02\end{array}$ \\
\hline $\begin{array}{l}\text { Total Flavanoids } \\
\text { (mg/ml) }\end{array}$ & $\begin{array}{c}0.47 \\
\pm 0.02\end{array}$ & $\begin{array}{l}0.58^{*} \\
\pm 0.01\end{array}$ & $\begin{array}{l}0.60 * \\
\pm 0.02\end{array}$ & $\begin{array}{l}0.73 * * \\
\pm 0.02\end{array}$ & $\begin{array}{c}0.60 \\
\pm 0.02\end{array}$ & $\begin{array}{l}0.73^{*} \\
\pm 0.04\end{array}$ & $\begin{array}{l}0.87 * * \\
\pm 0.03\end{array}$ & $\begin{array}{c}0.99 * * \\
\pm 0.02\end{array}$ & $\begin{array}{c}0.65 \\
\pm 0.02\end{array}$ & $\begin{array}{c}0.66 \\
\pm 0.02\end{array}$ & $\begin{array}{l}0.70^{*} \\
\pm 0.02\end{array}$ & $\begin{array}{l}0.76^{*} \\
\pm 0.02\end{array}$ \\
\hline
\end{tabular}

t-test: $* P<0.05 ; * * P<0.01 ; * * * P<0.001$

Table.3 Anthelmintic activity of $D$. hamiltonii fortified jaggery from different sugarcane varieties (Mean \pm Standard Deviation)

\begin{tabular}{|c|c|c|c|c|c|c|c|c|c|c|c|c|c|c|}
\hline $\begin{array}{c}\text { Sugarcane variety } \\
\text { D. hamiltonii } \\
\text { Concentration }\end{array}$ & \multicolumn{4}{|c|}{$\begin{array}{c}\text { Co } 86032 \\
(500 \mathrm{mg} / \mathrm{mL} \text { Jaggery solution) }\end{array}$} & \multicolumn{4}{|c|}{$\begin{array}{c}\text { Co } 419 \\
(500 \mathrm{mg} / \mathrm{mL} \text { Jaggery solution) }\end{array}$} & \multicolumn{4}{|c|}{$\begin{array}{c}\text { Co } 62175 \\
(500 \mathrm{mg} / \mathrm{mL} \text { Jaggery solution) }\end{array}$} & $\begin{array}{c}\text { Standard } \\
\text { Piperazine- } \\
\text { hexahydrate } \\
(10 \mathrm{mg} / \mathrm{mL}) \\
\text { Positive control }\end{array}$ & $\begin{array}{c}\text { Distilled } \\
\text { Water } \\
\text { Negative } \\
\text { control }\end{array}$ \\
\hline Paralytic time (min) & $\begin{array}{c}16.13 \\
\pm \\
1.20\end{array}$ & $\begin{array}{r}15.47 \\
\pm 0.55\end{array}$ & $\begin{array}{r}15.45 \\
\pm 1.09\end{array}$ & $\begin{array}{l}14.51 \\
\pm 1.14\end{array}$ & $\begin{array}{l}16.45 \\
\pm 2.10\end{array}$ & $\begin{array}{r}16.04 \\
\pm 1.00\end{array}$ & $\begin{array}{c}15.58 \\
\pm \\
0.59\end{array}$ & $\begin{array}{r}15.12 \\
\pm 1.02\end{array}$ & $\begin{array}{r}15.44 \\
\pm 1.40\end{array}$ & $\begin{array}{l}14.58 \\
\pm 0.46\end{array}$ & $\begin{array}{c}14.14 \\
\pm \\
1.08\end{array}$ & $\begin{array}{l}13.41 \\
\pm 1.30\end{array}$ & $\begin{array}{r}23.08 \\
\pm 1.00\end{array}$ & - \\
\hline Death time (min) & $\begin{array}{c}20.23 \\
\pm \\
2.20\end{array}$ & $\begin{array}{l}19.48 \\
\pm 1.05\end{array}$ & $\begin{array}{r}19.13 \\
\pm 1.08\end{array}$ & $\begin{array}{r}18.39 \\
\pm 0.58\end{array}$ & $\begin{array}{r}19.44 \\
\pm 1.30\end{array}$ & $\begin{array}{r}19.19 \\
\pm 1.14\end{array}$ & $\begin{array}{c}18.53 \\
\pm \\
1.23\end{array}$ & $\begin{array}{l}18.16 \\
\pm 2.07\end{array}$ & $\begin{array}{r}19.46 \\
\pm 1.00\end{array}$ & $\begin{array}{r}19.13 \\
\pm 1.05\end{array}$ & $\begin{array}{c}18.52 \\
\pm \\
0.57\end{array}$ & $\begin{array}{r}18.29 \\
\pm 1.27\end{array}$ & $\begin{array}{l}26.58 \\
\pm 1.20\end{array}$ & - \\
\hline
\end{tabular}


Fig.1 DPPH radical scavenging activity of $D$. hamiltonii fortified jaggery and Standard BHT $(* \mathrm{P}<0.05 ; * * \mathrm{P}<0.01 \& * * * \mathrm{P}<0.001)$

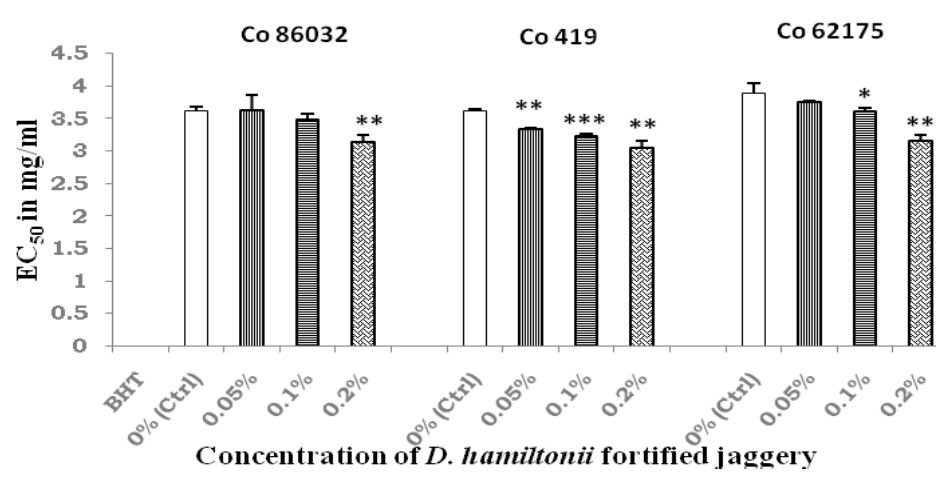

Fig.2 Reducing power of $D$. hamiltonii fortified jaggery and Standard Trolox $(* \mathrm{P}<0.05$; ** $\mathrm{P}<$ $0.01 \& * * * \mathrm{P}<0.001)$

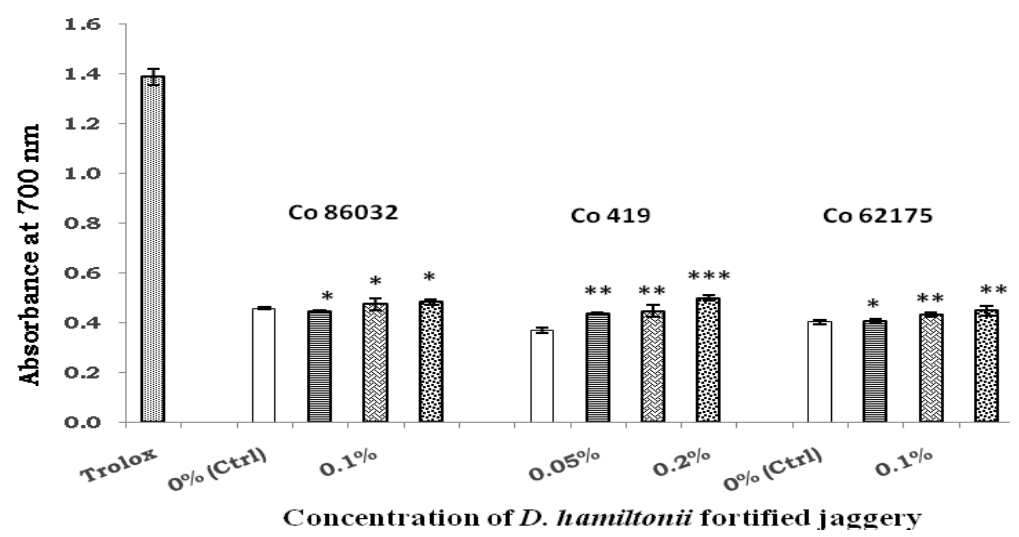

Fig.3 Anti-lipoxygenase activity of $D$. hamiltonii fortified jaggery and Standard Indomethacin $(* \mathrm{P}<0.05 ; * * \mathrm{P}<0.01 \& * * * \mathrm{P}<0.001)$

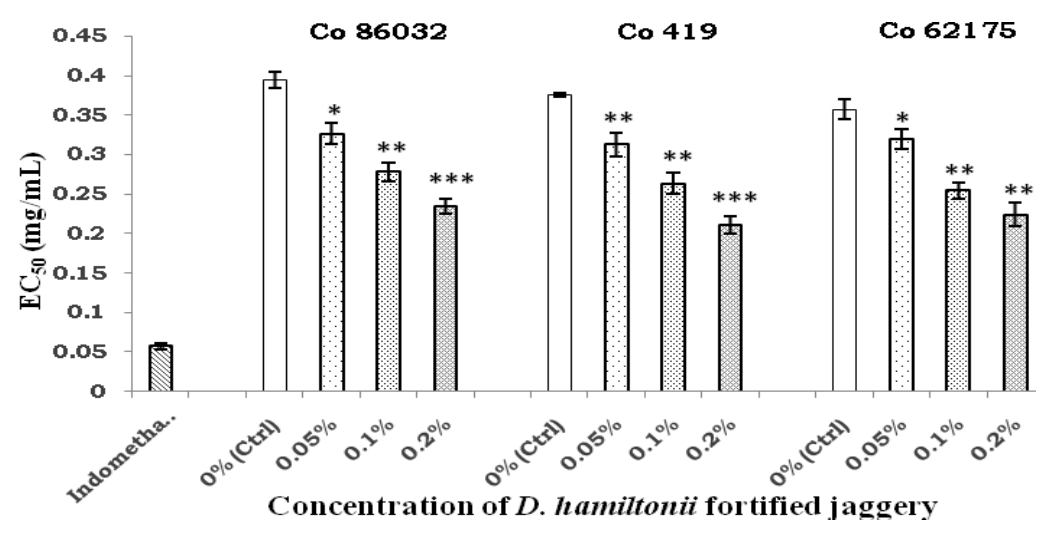


In addition, the reducing potentiality of an antioxidant quantified by using reducing power assay depends on the capability of an antioxidant to reduce ferric chloride and potassium ferricyanide complex monitored spectrophotometrically at $700 \mathrm{~nm}$.

The rise in absorbance of the reaction mixture was proportionate to reducing power ability. The reducing ability of an antioxidant narrates to its electron transfer capacity and serves as a substantial indicator of its potential antioxidant activity (Meir et al., 1995). Reducing potential of $D$. hamiltonii fortified jaggery and standard Trolox were presented in Figure 2. Fortified jaggery of all sugarcane varieties studied recorded increased absorbance at $700 \mathrm{~nm}$ and was dose proportional with $D$. hamiltonii fortification. The recorded data confirmed that Co 86032, Co 419 and Co 62175 fortified jaggery at $0.2 \%$ D. hamiltonii addition caused enhancement of reducing potential approximately by $5.23,34.47$ and $11.43 \%$, respectively from its control jaggery. On an average, the absorbance at $700 \mathrm{~nm}$ of both control and $D$. hamiltonii fortified jaggery samples were nearly three folds lower compared to standard antioxidant Trolox $(5 \mathrm{mg} / \mathrm{mL})$.

Various plant extracts have found application in food industries as natural preservatives to check lipid oxidation and microbial growth in food. The phenolic compounds present in plants has hydrogen donating capacity and are responsible for inhibition of free radical induced oxidation and hence exhibit antioxidant activity (Yen et al., 1993). Sugarcane juice is abundant with polyphenols and exhibited antioxidant potentiality (Duarte Almeida et al., 2006). Jaggery is prepared by boiling sugarcane juice; most of polyphenols are reserved in final product jaggery. Brazilian panela or jaggery reported to contain antioxidant vitamins viz., Vitamin A and Vitamin C (Bernal et al., 2004) and various phenolic glycosides present in jaggery attributed for strong free radical scavenging potential than synthetic antioxidant BHT (Takara et al., 2002).Our own earlier studies on jaggery have shown strong DPPH scavenging ability with EC50 $=7.81 \mu \mathrm{g} / \mathrm{mL}$ and reducing power with absorbance of 2.66 at $20 \mathrm{mg} \cdot \mathrm{mL}$ (Harish Nayaka et al., 2009). Enrichment of jaggery with spices like ginger and cardamom promoted its antioxidant activity (Harish Nayaka et al., 2015; Vinutha Chandrakanth et al., 2019). The aromatic tuberous root, $D$. hamiltonii well-known for its medicinal properties. Aqueous extracts of D. hamiltonii document its strong DPPH scavenging effect and reducing power (Srivastava et al., 2006b).

In this study, fortification of jaggery with $D$. hamiltonii statistically enhanced the total phenol and flavonoid contents in jaggery and marked positive correlation between total phenolic content and antioxidant potentiality. Similar positive correlation between total phenolic content and antioxidant activity in plants are documented (Benzie and Szeto, 1999). An antioxidant-rich natural sweetener may serves as a good source of neutraceuticals and plays a key role in maintenance of health and well-being.

\section{In-vitro antilipoxygenase activity of $\mathrm{D}$. hamiltonii fortified jaggery}

Most of the oxidative enzymes performing normal biological processes are also involved in pathological conditions. Lipoxygenase enzymes belong to such category are produced in body during pathological conditions and are mainly involved in biosynthetic pathways leading to formation of leukotrienes, a key mediators of allergic response, pain and inflammation. In human tissues, lipoxygenases are produced by immune cells like neutrophils, eosinophils 
and by platelets, synovial fluid, lung tissues and bone marrow cells (Steinhilber, 1999). Lipoxygenase catalyzes metabolic oxygenation reaction in cellular system and the resulting metabolites are important bioregulatory compounds viz., hydroperoxyeicosa-tetraenoic acids (HPETE), hydroxyeicosa-tetraenoic acid (HETE), leukotrienes and lipoxins that cause psoriasis, rheumatoid arthritis, glomerular nephritis, cancer, tumour, neuropathic and inflammatory pain (Sircar et al., 1983; Bhattacharjee, 2007). Continued administration of synthetic anti-inflammatory drugs for a long time had adverse side effects and therefore there is a demand to explore natural tactics to reduce the formation of inflammatory mediators through dietary products. In vitro lipoxygenase inhibitory activity of $D$. hamiltonii fortified jaggery was analyzed spectrophotometrically using linoleic acid as the substrate for the enzyme lipoxygeanase extracted from soybean. The enzyme converts the substrate linoleic acid into conjugated dienes that is monitored with increase in absorbance at $234 \mathrm{~nm}$ using UVspectrophotometer.

The inhibitory effect of fortified jaggery of three tested sugarcane varieties on soybean lipoxygenase activity was represented in Figure 3. The inhibitory effect of jaggery on soybean lipoxygenase was expressed in terms of $\mathrm{EC}_{50}$ values $(50 \%$ inhibitory concentration). The lipoxygenase activity in crude soybean extract noted as 32U. Control jaggery of all three sugarcane varieties evaluated documented 50\% inhibitory activity of enzyme at $0.37 \mathrm{mg} / \mathrm{mL}$ and reference standard indomethacin showed an $\mathrm{EC}_{50}$ of $57.2 \mu \mathrm{g} / \mathrm{mL}$. D. hamiltonii fortified jaggery appraised greater lipoxygenase inhibitory effect and was proportional to fortified spice concentration. At $0.05 \%$ D. hamiltonii fortification, jaggery had $\mathrm{EC}_{50}$ of $0.33,0.31$ and $0.32 \mathrm{mg} / \mathrm{mL}$ for Co 86032, Co 419 and Co 62175 jaggery varieties, respectively.
Further, correlation coefficient between total phenol content and lipoxygenase inhibitory activity of fortified jaggery were calculated. A good positive correlation $(\mathrm{r}=0.967,0.894$ and 0.964) was recorded for Co 86032, Co 419 and Co 62175 jaggery, respectively between phenolics and enzyme inhibitory action. Plant polyphenols work as crucial regulators of biological oxidation and demonstrated supposedly beneficial inhibitory action of inflammatory enzyme, lipoxygenase. Hence, phenolics application for the management of inflammatory diseasesrecommended earlier (Sreejayan and Rao, 1996). Lipoxygenases are susceptible to antioxidants; antioxidants inhibit lipoxygenase by scavenging free radicals and thereby, antioxidants are good antiinflammatory compounds as they impede formation of lipid-hydroperoxide, an intermediate metabolite of lipoxygenase action by scavenging lipid-oxy or lipidperoxy radicals (Rackova et al., 2007). Further, antioxidants can also hinder lipoxygenase action via non-heme bound-iron chelation (Lin et al., 2001) and iron reduction (Gutierrez-Lugo et al., 2004).

Phytochemicals like phenolics and flavonoids documented to modulate the activity of lipoxygenase (Laughton et al., 1991) by inhibiting lipoxygenase activity and blocking arachidonic acid metabolic pathway. Active principles of spices considered as good inhibitors of lipoxygenase enzyme and showed synergetic inhibitory effect on enzyme activity (Prasad et al., 2004). The results of in vitro analyzes of lipoxygenase activity reveal that polyphenols of $D$. hamiltonii has contributed for lipoxygenase inhibitory effect of jaggery of all tested varieties and henceforth, jaggery fortification with $D$. hamiltonii may enrich jaggery with supplementary health benefit to combat inflammation. 
In-vitro antihelmintic activity of $\mathrm{D}$. hamiltonii fortified jaggery

Helminthiasisis the most mistreated tropical disease and imposed a great risk on human health and economy of the world. Poor sanitation, unsafe water, poverty, malnutrition and unawareness in the society have favored its propagation in humans and livestock (Brooker et al., 2006). Helminth or worm infections have endured moderately high over time; women and children are more susceptible for helminthiasis (Jinabhai et al., 2001). Normally, helminth infection do not cause noticeable ailment in humans. However, helminth's metabolic activities and toxic excretory products affect host's health integrity (Deacon, 2006).

Further, helminthias is influences host's body for higher vulnerability to bacterial and other opportunistic infections (Bentwich et al., 1995; Brooker et al., 2004). The antihelmintic drugs are expensive, often out of reach for the public. Most of helminthes have established rapid resistance for these drugs (Melo et al., 2003). In traditional system of medicine, a number of medicinal plants are used for the treatment of helminth infection since decades (Waller et al., 2001). There is a great potential for discovery and development of effective drug from natural plant source against gastrointestinal parasites. In vitro antihelmintic activity of $D$. hamiltonii fortified jaggery of three-tested cane varieties studied using earthworms and the results revealed that no statistically significant difference both in paralytic and death time of helmintiasis between control and fortified jaggery of all sugarcane varieties as tabulated in Table 3 . Control and $D$. hamiltonii fortified jaggery observed for uniform antihelmintic activity. The observed death time of worm was between $18-20 \mathrm{~min}$ at $0.5 \mathrm{~g} / \mathrm{mL}$ jaggery concentration. The killing time of earthworms by the standard drug piperazine hexahydrate was $26.58 \mathrm{~min}$ at $10 \mathrm{mg} / \mathrm{mL}$ concentration. However, distilled water did not shown any effect on life of helminthes and served as negative control. Further, jaggery concentration to bring about helminthic paralysis was approximately 50 folds higher compared to standard drug piperazine hexahydrate. Flaccid paralysisof the worm was the predominant effect of piperazine hexahydrate that resulted in expulsion of the worm by peristalsis. Jaggery prepared from sugarcane juice and palm sap sources demonstrated antihelmintic activity (Prasad et al., 2010). Further, jaggery has acidic $\mathrm{pH}$ and contains mixture of sugars that results in low water activity.

The acidic $\mathrm{pH}$ and saturated sugars makes unfavorable condition for growth ofhelminthes in gastrointestinal tract. In addition, polyphenolic compounds are known to exhibitantihelmintic activity (Bate-Smith, 1962). Literature revealedthat tannins displayed antihelmintic activity (Athnasiadou et al., 2001). Phenolic compounds found to uncouple oxidative phosphorylation and halt respiration and thus mediate death of helminth parasites (Martin, 1997). The results revealed that the enhanced phenolic components in jaggery upon fortification with $D$. hamiltonii are not enough to bring down the death time of helmintic parasites.

In conclusion the fortification of sugarcane jaggery with $D$. hamiltonii root extract imparts good coloration to jaggery in addition to increased turbidity, insoluble solid contents and lower filterability. Further, no change in key chemical constituents like sucrose, and reducing sugar content was evident. However, enhanced total protein, phenolics and flavonoid content was observed. The enhanced phenolics and flavonoid content might be responsible for the exhibited higher DPPH radical scavenging, reducing power and lipoxygenase inhibitory activity. Hence, 
D. hamiltonii fortified jaggery of sugarcane varieties Co 86032, Co 419 and Co 62175 might be used as a nutraceutical sweetener for its observed health benefits.

\section{Acknowledgment}

The authors wish to thank the Department of Sugar Technology, Sir M. Visvesvaraya Post Graduate Centre, University of Mysore, Mandya 571 402, Karnataka, India for providing infrastructure for the research work. The first author acknowledges Department of Science and Technology, New Delhi, India for awarding the INSPIRE fellowship.

\section{Compliance with Ethical Standards}

Conflict of Interest: The authors declare that they have no conflict of interest.

Funding: Funding provided by the INSPIRE Fellowship, Department of Science and Technology, Ministry of Science and Technology (Grant No. IF 110208, Inspire Fellowship).

\section{References}

Adelaja, A.O., and B.J. Schilling. 1999. Nutraceutical: blurring the line between food and drugs in the twenty-first century. Choices 14: 35-39.

Ames, B.N., M.K. Shigenaga, and T.M. Hagen. 1993. Oxidants, antioxidants and degenerative diseases of aging. Proceedings of the National Academy of Sciences of the United States of America 90: 7915-7922.

Anon. 1999. ICUMSA METHODS, 2002 Updates. Method GS1/2/3- 2, p. 6.

Anonymous. 1990. Bureau of Indian Standards, IS 12923, 1990: (Clause 4.3 and 6.1), New Delhi, India.

Anwaar, S.I., and J. Singh. 2010. Modified pans for open pan jaggery furnace.
Lucknow: Operation Manual No. AE/10/01, Indian Institute of Sugarcane Research.

Athnasiadou, S., I. Kyriazakis, F. Jackson, and R.L. Coop. 2001. Direct anthelmintic effects of condensed tannins towards different gastrointestinal nematodes of sheep: In vitro and in vivo studies. Veterinary Parasitology 99: 205-219.

Bate-Smith, E.C. 1962. The phenolic constituent of plants and their taxonomic significance. I. Dicotyledons. The Journal of the Linnean Society, Botony 58: 95-103.

Bentwich, Z., A. Kalinkovich, and Z. Weisman. 1995. Immune activation is a dominant factor in the pathogenesis of African AIDS. Immunology Today 16: 187-191.

Benzie, I.F.F. and Y.T. Szeto. 1999. Total antioxidant capacity of teas by the ferric reducing/antioxidant power assay. Journal of Agricultural and Food Chemistry 47: 633-636.

Bernal, H.R.G., A.X.J. Guzman, and A.R.A. Jimenez. 2004. Caracterizacion Nutricional de la panela granulada. Corpoica 4: 34-42.

Beuchat, L.R. 1981. Microbial stability as affected by water activity. Cereal Foods World 26: 345-349.

Bhattacharjee, S. 2007. Reactive oxygen species and oxidative brust; roles in stress, senescence and signal transduction in plants. Current Science 89: 1113-1121.

Blios, M.S. 1958. Antioxidant determinations by the use of astable free radical. Nature 181:1199-1200.

Braca, A., C. Sortino, M. Politi, I. Morelli, and J. Mendez. 2002. Antioxidant activity of flavonoids from Licania licaniaeflora. Journal of Ethnopharmacology79: 379-381.

Bradford, M.M. 1976. A rapid and sensitive 
method for the quantification of microgram quantities of protein utilizing the principle of protein-dye binding. Analytical Biochemistry 72: 248-254.

Brooker, S., J. Bethony, and P.J. Hotez. 2004. Human hook worm infection in the $21^{\text {st }}$ century. Advances in Parasitology 58: 197-288.

Brooker, S., N. Alexander, S. Geiger, R.A. Moyeed, J. Stander, F. Fleming, P.J. Hotez, R. Correa-Oliveira, and J. Bethony. 2006. Contrasting patterns in the small-scale heterogeneity of human helminth infections in urban and rural environments in Brazil. International Journal of Parasitology 36: 1143-1151.

Brown, J.E. and C.A. Rice-Evans. 1998. Luteolin-rich artichoke extract protects low-density lipoprotein from oxidation in Vitro. Free Radical Research29: 247255.

Burton, H.S., and D.J. McWeeny. 1963. Nonenzymic browning reactions: Consideration of sugar stability. Nature 197: 266-268.

Burton, H.S., D.J. McWeeny, and D.O. Biltcliffe. 1963. Non-enzymic browning-development of chromophores in glucose-glycine and sucrose-glycine systems. Journal of Food Science 28: 631-639.

Chang, C., M. Yang, H. Wen, and J. Chern. 2002. Estimation of total flavonoid content in propolis by two complementarycolorimetric methods.JournalofFoodandDrugAnalysi s10:178-182.

Chen, C.W., and C.T. Ho. 1995. Antioxidant properties of polyphenols extracted from green tea and black tea. Journal of Food Lipids 2: 35-46.

Craft, B.D., A.L. R. Kerrihard, Amarowicz, and R.B. Pegg. 2012. Phenol-based antioxidants and the in vitro methods used for their assessment. Comprehensive Reviews in Food
Science and Food Safety11: 148-173.

Deacon, J.W. 2006. Fungal Biology. Blackwell Publishing, Oxford, United Kingdom.

Denys, J.C. 2013. Antioxidant properties of spices, herbs and other sources. Springer, New York, Heidelberg Dordrecht, London.

Devarajan, T., S. Anitha, T. Pullaiah, P. Narasimha Reddy, and O.S. Ramachandraiah. 2002. Essential Oil Constituents and In Vitro Antimicrobial Activity of Decalepis Hamiltonii Roots Against Foodborne Pathogens. Journal of Agricultural and Food Chemistry50: 3147-3149.

Dillard, C.J., and J.B. German. 2000. Phytochemicals: nutraceuticals and human health. Journal of the Science of Food and Agriculture 80: 1744-1756.

Duarte-Almeida, J.M., A.V. Novoa, A.F. Linares, F.M. Lajolo, and M.I. Genovese. 2006. Antioxidant activity of phenolics compounds from sugarcane (Saccharum officinarum L.) juice. Plant Foods for Human Nutrition 61: 187192.

Duthie, G., and A. Crozier. 2000. Plantderived phenolic antioxidants. Current Opinion in Lipodology 11: 43-47.

Ecuadorian Technical Standard NTE INEN 2 332. 2002. Panela Granulada Requisitos, p. 2 Quito-Ecuador.

Ferrazzano, G.F., I, Amato, A. Ingenito, A. Zarrelli, G. Pinto, and A. Pollio. 2011. Plant polyphenols and their anticariogenic properties: A review. Molecules 16: 1486-1507.

Fontaniella, B., C. Vicente, M.E. Legaz, R. De Armas, C.W. Rodriguez, and M. Martinez. 2003. Yellow leaf syndrome modifies the composition of sugarcane juices in polysaccharides, phenols and polyamines. Plant Physiology and Biochemistry41: 1027-1036.

Ghasemzadeh, A., and N. Ghasemzadeh. 
2011. Flavonoids and phenolic acids: Role and biochemical activity in plants and human. Journal of Medicinal Plants Research 5: 6697-6703.

Grice, H.P. 1988. Enhanced tumour development by butylated hydroxyanisole (BHA) from the prospective of effect on fore stomach and oesophageal squamous epithelium. Food and Chemical Toxicology 26: 717-723.

Guan, Y., Q. Chu, L. Fu, T. Wu, and J. Ye. 2006. Determination of phenolic antioxidants by micellar electrokinetic's capillary chromatography with electrochemical detection. Food Chemistry 94: 157-162.

Guerra, M.J., and M.V. Mujica. 2010. Physical and chemical properties of granulated cane sugar "panelas". Ciencia e Tecnologia de Alimentos Campinas 30: 250-257.

Gutierrez-Lugo, M.T., J.D. Deschamps, T.R. Holman, E. Suarez, and B.N. Timmermann. 2004. Lipoxygenase inhibition by anadanthoflavone, a new flavonoid from the aerial parts of Anadenanthera colubrina. Planta Medica 70: 263-265.

Halliwell, B. 2007. Biochemistry of oxidative stress. Biochemical Society Transactions 35: 1147-1150.

Harish Nayaka, M.A., U.V. Sathisha, M.P. Manohar, K.B. Chandrashekar, and M.D. Shylaja. 2009. Cytoprotective and antioxidant activity studies of jaggery sugar. Food Chemistry 115: 113-118.

Harish Nayaka, M.A., C. Vinutha, S. Sudarshan, and M.P. Manohar. 2015. Physico-chemical, antioxidant and sensory attributes of ginger (Zingiber officinale) enriched jaggery of different sugarcane varieties. Sugar Tech 17: 305-313.

Helrich, K. 1990. Official methods of analysis of the Association of Official Analytical
Chemists, 15th ed, 777-778. Washington DC: AOAC International Publisher.

Hodge, J.E. 1953. Dehydrated foods, chemistry of browning reactions in model systems. Journal of Agricultural and Food Chemistry 1: 928-943.

Jagannadha Rao, P.V.K., D. Madhusweta, and S.K. Das. 2007. Jaggery- A Traditional Indian Sweetener. Indian Journal of Traditional Knowedge 6: 95-102.

Jinabhai, C.C., M. Taylor, A. Coutsoudis, H.M. Coovadia, A.M. Tomkins, and K.R. Sullivan. 2001. Epidemiology of helminth infections: implications for parasite control programmes, a South African perspective. Public Health Nutrition 4: 1211-1219.

Khan Chand., Anupama Singh, and A.K. Verma. 2011. Quality evaluation of jaggery chocolates under various storage conditions. Sugar Tech 13: 150155

Knekt, P., R. Jarvinen, A. Reunanen, and J. Maatela. 1996. Flavonoid intake and coronary mortality in Finland: A cohort study. British Medical Journal 312: 478-481.

Lane, J.H., and L. Eynon. 1923. Volumetric determination of reducing sugars by means of Fehling's solution with methylene blue as internal indicator. Journal of Chemical Society India Transations 42:32-37.

Laughton, M.J., P.J. Evans, M.A. Moroney, J.R.S. Hoult, and B. Halliwell. 1991. Inhibition of mammalian 5lipoxygenase and cyclooxygenase by flavonoids and phenolic dietary compounds. Biochemical Pharmacology 43: 1673-1681.

Lin, J.K., S.H., Tsai, and S.Y. Lin-Shiau. 2001. Antiinflammatory and antitumor effects of flavonoids and flavonoids. Drugs of the Future 26: 145157. 
Lu, J., P.H. Lin, Q. Yao, and C. Chen. 2010. Chemical and molecular mechanisms of antioxidants: experimental approaches and model systems. Journal of Cellular and Molecular Medicine 14: 840-860.

Mandal, D., S.R. Tudu, and G.C. De Mitra. 2006. Effect of common packing material on keeping quality of sugarcane Jaggery during monsoon season. Sugar Tech 8: 2-3.

Martin, R.J. 1997. Mode of action of anthelmintic drugs. Veterinary Journal 154: 11-34.

Meir, S., J. Kanner, B. Akiri, and S.P. Hadas. 1995. Determination and involvement of aqueous reducing compounds in oxidative defense systems of various senescing leaves. Journal of Agricultural and Food Chemistry 43: 1813-1817.

Melo, A.C.F.L., I.F. Reis, C.M.L. Bevilaqua, L.S. Vieira, F.A.M. Echevarria, and L.M. Melo. 2003. Nematodeos resistentes a antihelmíntico em rebanhos de ovinos e caprinos do estado do Ceara, Brasil. Ciencia Rural 33: 339344.

Naidu, K.A. 1995. Eugenol: An inhibitor of lipoxygenase dependent lipid peroxidation. Prostaglandins Leukotrienes Essential Fatty Acids 53: 381-383.

Nayar, R.C., J.K.P. Shetty, Z. Mary, and S.N. Yoganarasimhan. 1978. Pharmacological studies of root of Decalepis hamiltonii (Wight and Arn.) and comparison with Hemidesmus indicus (L.). Proceedings of the National Academy of Sciences 87: 3748.

Nrashant S., D. Kumar, S. Raisuddin, and P.S. Anand. 2008. Genotoxic effects of arsenic: Prevention by functional foodJaggery. Cancer Letters 268: 325-330.

Okabe., T.T. Toda, M. Inafuku, K. Wada, H. Iwasaki, and H. Oku. 2009.
Antiatherosclerotic functions of kokuto, Okinawan non-centrifuged cane sugar. Journal of Agricultural and Food Chemistry 57: 69-75.

Prasad, N.S., R. Raghavendra, B.R. Lokesh, and K.A. Naidu. 2004. Spice phenolics inhibit human PMNL 5-lipoxygenase. Prostaglandins, Leukotrienes and Essential Fatty Acids 70: 521-528.

Prasad, P., P. Praveen Kumar, K. Satyavathi, and M.C. Prabhakar. 2010 Comparatives studies on anthelmintic activity of natural sweeteners. Research Journal of Pharmaceutical Biological and Chemical Sciences 1: 510-514.

Rackova, L., M. Oblozinsky, D. Kostalova, V. Kettmann, and L. Bezakova. 2007. Free radical scavenging activity and lipoxygenase inhibition of Mahonia aquifolium extract and isoquinoline alkaloids. Journal of Inflammation 4: 15-22.

Rice-Evans, C.A., N.J. Miller, P.G. P.M. Bolwell, Bramley, and J.B. Pridham. 1995. The relative antioxidant activities of plant derived polyphenolic flavonoids. Free Radical Research22: 375-383.

Robertson, R.P. and J.S. Harmon. 2006. Diabetes, glucose toxicity, and oxidative stress: a case of double jeopardy for the pancreatic islet b-cell. Free Radical Biology and Medicine 41: 177-184.

Sahu, A.P., and A.K. Saxena. 1994. Enhanced translocation of particles from lungs by jaggery. Environmental Health Perspectives 102: 211-214.

Scalbert, A., I.T. Johnson, and M. Saltmarsh. 2005. Polyphenols: antioxidants and beyond. American Journal of Clinical Nutrition 81: 2155-2175.

Sies, H. 1993. Strategies of antioxidant defense. European Journal of Biochemistry 215: 213-219.

Singh, U., and I. Jialal. 2006. Oxidative stress and atherosclerosis. Pathophysiology 
13: 129-142.

Singleton, V.L., R. Orthofer, and R.M. Lamuela-Raventos. 1999. Analysis of total phenols and other oxidation substrates and antioxidants by means of Folin-Ciocalteu reagent. Methods in Enzymology 299: 152-178.

Sircar, J.C., C.F. Schwender, and E.A. Johnson. 1983. Soybean lipoxygenase inhibition by non-steroidal antiinflammatory drugs. Prostaglandins 25: 393-396.

Smid, E.J., and L.G.M. Gorris. 1999. Natural antimicrobials for food preservation. In Handbook of Food Preservation (M.S. Rahman, ed.) 285-308, Maarcel Dekker, New York.

Sreejayan, N., and M.N.A. Rao. 1996. Free radical scavenging activity of curcuminoids. Arzneimittel-Forschung 46: 169-171.

Srikanta, B.M., M.A. Harish Nayaka, and M.D. Shylaja. 2011. Inhibition of Helicobacter pylori growth and its cytotoxicity by 2-hydroxy 4-methoxy benzaldehyde of Decalepis hamiltonii (Wight \& Arn); a new functional attribute. Biochimie 93: 678-688.

Srivastava, A., R. Harish, and T. Shivanandappa. 2006a. Novel antioxidant compounds from the aqueous extract of the roots of Decalepis hamiltonii (Wight and Arn.) and their inhibitory effect on lowdensity lipoprotein oxidation. Journal of Agricultural and Food Chemistry 54: 790-795.

Srivastava A., S.R. Harish, and T. Shivanandappa. 2006b. Antioxidant activity of the roots of Decalepis hamiltonii (Wight \& Arn.). LWT- Food Science and Technology 39: 1059-1065.

Steinhilber, D. 1999. 5-Lipoxygenase: a target for anti-inflammatory drugs revisited. Current Medicinal Chemistry 6: 69-83.

Takara, K., D. Matsui, K. Wada, T. Ichiba, and Y. Nakasone. 2002. New antioxidative phenolic glycosides isolated from kokuto, non-centrifugal cane sugar. Bioscience Biotechnology and Biochemistry 66: 29-35.

Tomasik, P., M. Palasinski, and S. Wiejak. 1989. Advances in carbohydrate chemistry and biochemistry. In: Thermal decomposition of carbohydrates: Part I-the decomposition of mono-, di and oligosaccharides. Ed. Tipson, R. S and Horton, D., Academic press, Inc., San Diego, CA, 203-255.

Valko, M., Rhodes, C.J., Moncola, J., Izakovic, M. and Mazura, M. 2006. Free radicals, metals and antioxidants in oxidative stress-induced cancer. Chemico-Biological Interactions 160 : $1-40$.

Vineet Kumar, Anita Rani, Vimal Pandey, G. S. Chauhan. 2006. Changes in lipoxygenase isozymes and trypsin inhibitor activity in soybean during germination at different temperatures. Food Chemistry 99: 563-568.

Vinutha, C., S. Sudarshan, S. Pradeep, and M.A. Harish Nayaka. 2014. Antioxidant activity of sugarcane jaggery with neem (Azadirachta indica) leaf extract. International Journal of Recent Scientific Research 5: 99-101.

Vinutha Chandrakanth, Harish Nayaka Mysore Annaiah, Sudarshan Shivalingaiah and Lava Chikkappaiah. 2019. Cardamom [Elettaria cardamomum (L.) Maton]-fortified jaggery: Its physicochemical characterization and in vitro antioxidant capacity. Sugar Tech 21:388-397.

Waller, P.J., G. Bernes, S.M. Thamsborg, A. Sukura, S.H. Richter, K. Ingebrigtsen, and J. Hoglund. 2001. Plants as deworming agents of livestock in the Nordic countries: historical perspective, popular beliefs and prospects for the future. Acta Veterinaria Scandinavica 
42: 31-44.

Wang, M., J. Li, M. Rangarajan, Y. Shao, E.J. La voie, T.C. Huang, and C.T. Ho. 1998. Antioxidative phenolic compounds from sage (Salvia officinalis). Journal of Agricultural and Food Chemistry46: 4869-4873.

Wichi, H.C. 1986. Safety evaluation of butylated hydroxytoluene (BHT) in the liver, lung and gastrointestinal tract. Food and Chemical Toxicology 24: 1127-1130.

Yamaguchi, T., H. Takamura, T. Matoba, and J. Terao. 1998. HPLC method for evaluation of the free radical scavenging activity of foods by using 1,1-diphenyl2-picrylhydrazyl. Bioscience, Biotechnology, and Biochemistry 62: 1201-1204.

Yen, G.C., and H.Y. Chen. 1995. Antioxidant activity of various tea extracts in relation to their antimutagenicity. Journal of Agricultural and Food Chemistry 43: 27-32.

Yen, G.C., P.D. Duh, and C.L. Tsai. 1993. The relationship between antioxidant activity and maturity of peanut hulls. Journal of Agricultural and Food Chemistry 41: 67-70.

\section{How to cite this article:}

Vinutha, C., M. A. Harish Nayaka, G. Sowmyashree and Dinesh Kumar. 2021. Decalepis hamiltonii (Wight \& Arn.) Fortified Jaggery: Its Physico-chemical Characterization and Studies on its In vitro Biological Activities. Int.J.Curr.Microbiol.App.Sci. 10(01): 1510-1529 doi: https://doi.org/10.20546/ijcmas.2021.1001.178 